\title{
Analyzing international city networks for sustainability: A study of five major Swedish cities
}

\author{
Santiago Mejia-Dugand, Wisdom Kanda and Olof Hjelm
}

Linköping University Post Print

Tweet

N.B.: When citing this work, cite the original article.

Original Publication:

Santiago Mejia-Dugand, Wisdom Kanda and Olof Hjelm, Analyzing international city networks for sustainability: A study of five major Swedish cities, 2015, Journal of Cleaner Production.

http://dx.doi.org/10.1016/j.jclepro.2015.09.093

Copyright: Elsevier http://www.elsevier.com/

Postprint available at: Linköping University Electronic Press

http://urn.kb.se/resolve?urn=urn:nbn:se:liu:diva-121814 


\title{
Analyzing international city networks for sustainability: A study of five major Swedish cities
}

\author{
Santiago Mejía-Dugand ${ }^{* 1}$, Wisdom Kanda ${ }^{1}$, Olof Hjelm ${ }^{1}$ \\ ${ }^{1}$ Environmental Technology and Management, Department of Management and Engineering, \\ Linköping University, SE-581 83 Linköping, Sweden \\ * Corresponding author: Tel.: +46 13 285639; fax: +4613149403 \\ E-mail addresses: santiago.mejia.dugand@liu.se (S. Mejía-Dugand), wisdom.kanda@liu.se (W. \\ Kanda), olof.hjelm@liu.se (O. Hjelm)
}

\begin{abstract}
This article studies five Swedish cities, their membership in international city networks, the different motivations for such membership, and their administrations' expected and perceived benefits. Particular focus is put on sustainability, environmental technology, and municipal companies as potential beneficiaries of such network membership. This study is motivated by the fact that city networks can potentially contribute to global sustainability goals by accelerating the diffusion of innovations, giving members access to bidirectional information flows, improving the user-producer relationship, and providing legitimacy in the potential recipient regimes.

The study relies on a documentation review, the collection of data from the websites of the studied cities and numerous international city networks, and interviews with city officials responsible for international city networks. It was found that four of the five studied cities are active members of international networks for sustainability, but also that there are large gaps between the two largest cities and the rest when it comes to the number of memberships and the geographical outreach they have through the networks they belong to.

Some city officials claim that it is easier to be active in national networks than in international networks, due to time requirements and coordination among so many members. However, city officials see benefits for their municipal companies when they are members of international networks, and these companies are usually independent when it comes to choosing and administering their memberships. It was found that it is difficult to measure direct benefits from network membership, and link improvements in the studied cities to participation in a particular network (with the exception of groups created for a specific infrastructure project, reported as "networks" by the administrations). In addition, there is no apparent direct correlation between membership and diffusion of environmental solutions from municipal companies. However, the administrations expect indirect benefits such as gaining legitimacy and access to milieus where they can share information and best practices, which could lead to the improvement of both local and global environmental conditions.
\end{abstract}

Keywords: Legitimacy; Information Flows; Knowledge Sharing; Municipal Companies; Environmental Technology.

\section{Introduction}


Cities have recently become popular units of analysis for scholars and researchers in many fields related to sustainability (Bulkeley and Betsill, 2005; Nicholls, 2008). This is in great part due to the fact that humanity has never lived as densely as it does today. Although such conditions have been driven in part by the need to concentrate services and improve the reach of utilities and amenities, it has represented a significant impact on the surrounding environment and on the environmental services humans rely on in the first place.

In this line of thought, it is possible to understand the attention that cities are getting on the world agenda. By "world agenda" we mean not only a political one, but one that includes other components of the world's social dynamics, such as economy and science, the environment, and even arts and leisure (see e.g. Keiner and Kim, 2007; Nicholls, 2008; The World Bank, 2010; UNHABITAT, 2012). In particular, the ever-changing characteristics of city dwellers are of interest, due to the importance this has on the way cities are seen and experienced, and especially on how decisions are made regarding possible solutions to their problems (Hillman et al., 2010).

Since environmental technologies are considered to provide strong foundations for both environmental and economic sustainability (Kanda et al., 2013), the urban era represents opportunities for their diffusion. In this line of thought, cities that have historically enjoyed international visibility, reached advanced industrialization levels, and made headway in scientific advances are exploiting this condition, creating strategies and devoting important resources to promote their environmental technology expertise (Hodson and Marvin, 2009; 2010). Nevertheless, the difficulties of translating imaginaries of sustainability are becoming a concern for researchers, decision-makers and businesspeople alike. Hult (2013), for instance, highlights the difficulties that the Swedish government and its trade council (called Business Sweden) have faced when trying to export their urban development concept by using a marketing tool called SymbioCity. Such difficulties rest on the fact that the holistic approach proposed with this tool is tied to Swedish lifestyles and particular conditions that have facilitated the development and stability of these solutions at home. This can very well be a problem that many other technology providers face, since components of such solutions have grown in an orchestrated manner with local, coexisting systems and have developed in close proximity to them, something that Mejía-Dugand et al. (2013) also highlight.

In particular, technologies emerging at the municipal level (e.g. energy, waste, and wastewater management systems) face significant barriers in their diffusion. Municipal companies (in this context, mainly utility companies) have been developing solutions and know-how through many years of administering their cities (see e.g. Furlong, 2014). This has left them with valuable knowledge and expertise, which in turn represents opportunities for exploiting them from an economic perspective. However, municipal companies do not necessarily play on the same field as private companies, and thus must overcome different obstacles when thinking of benefitting from their knowledge (Kanda, 2014). Because of their nature, including the environmental solutions they provide, municipal companies often have other cities, governments and publicly owned companies as customers, often compared to business-to-business (B2B) customers in the case of private companies. Taking Swedish municipal companies as an example, Kairento and Nygårds (2014) identified barriers in their study related to human resource constraints between foreign markets and local responsibilities, lack of 
knowledge about foreign markets and also the difficulties of marketing intangible service offerings. Municipal ownership also induces split political vs. market incentives in diffusion (Kairento and Nygårds, 2014). Swedish municipalities have been developing programs to attract international attention to their solutions, e.g. foreign delegations, conferences, and field trips. However, such initiatives take a long time from participation to project realization. In addition, they have not had the expected results so far (Kanda, 2014; Mejía-Dugand, 2013).

It is commonly accepted in the innovation literature that diffusion is facilitated by the creation and maintenance of personal connections (see e.g. Pedersen, 1970; Baptista, 2001; Simmie, 2003; Keiner and Kim, 2007). The main argument of this article is that by understanding and taking advantage of the local, regional and international positioning of a city or group of cities, the process of diffusion of urban innovations, in particular those focused on sustainability issues, can be facilitated. By becoming part of international city networks, cities can have access to knowledge that is collectively supported, maintained, nurtured, and shared. In this article, the concept of networks is understood as a group of two or more cities that come together to create milieus in which they can share resources, knowledge, and experiences, and facilitate learning about a particular and explicitly defined topic.

Most importantly, and in line with the discussion presented above about the translation of urban imaginaries, city networks can provide legitimacy to their members. This is something that Kanda (2014) highlights as an essential requirement for the diffusion of environmental technologies, especially at the municipal level (cf. with private companies implementing environmental technologies based on market signals or providers' reputation). Benefits of making use of this knowledge include: entering a flow of incremental innovation that might facilitate the diffusion process (Cooke et al., 2002) and benefiting from two-way information flows (Batten, 1995); pacifying the competing logics in social and environmental innovations (Guy and Marvin, 1999); finding key compatibility factors between the innovation and the governing regimes and developing flexible and complementary/adaptive solutions (Batten, 1995; Mejía-Dugand et al., 2013); improving user-producer relations (Cooke et al., 2002); and maximizing the network value of an innovation (Cooke et al., 2002).

City networks can thus be particularly beneficial for the diffusion of environmental technologies from municipalities, which in the case of Sweden face several challenges and constraints, as mentioned above. The aim of this study is therefore to understand the dynamics of city networks and how their members benefit from their membership in them. This is done by studying the five largest cities in Sweden and the networks they belong to. We are interested in learning and diffusion of knowledge and environmental technologies. A special focus on municipal companies is central, since they concentrate a large share of this knowledge, and administrate the systems and technologies that operationalize it. This aim is supported by the following questions:

- To what extent do the studied cities participate in city networks for sustainability?

- In which way do municipal companies benefit from their city's membership in international networks when it comes to the diffusion of their environmental technologies? 
Competition between and among cities has shown to bring individual benefits in many cases, but it is not clear that this has been the case for the achievement of collective goals such as global sustainability, since unilateral actions have small chances of success (Hansson, 2010). Cities cannot build isolated and individual foundations for a sustainable future, especially in a globalized context where humans, capital, goods, and labor are highly free to move, stay or leave. The globalization process, Capello (2000) claims, provides a rational explanation for network behavior. Although Guy and Marvin (1999) mentioned that competing visions of sustainable cities emerge due to the diverse nature and composition of groups and collective goals aiming at sustainability, Keiner and Kim (2007) found that competition is less important when cities form networks for sustainability, since they all have the same goals. This is of particular importance when trying to understand the behavior of innovation diffusion for the solution of urban problems and the way in which knowledge is shared among the members of these networks.

\section{Sustainability: A global, rather than local goal}

Cities are acknowledged as crucial components of the most important global sustainability goals (Bulkeley and Betsill, 2005; Marceau, 2008). However, when taking the city as an element, urban sustainability takes a strictly geographically bounded shape. This fact can contradict the pursuit of global sustainability, since unilateral efforts have small chances of success (Hansson, 2010). It is clear that the diffusion of environmental technologies not only has the intention of contributing to sustainability, but also to propel economic growth (Kanda et al., 2015). In particular, and in relation to this article, this fact has motivated the emergence of strong competition among cities in international markets, not least in technology and other knowledge-based sectors (Marceau, 2008; Simmie, 2003). Considering the dominant economic system, this fact cannot be ignored or analyzed separately from sustainability. However, in this article we will put more effort into discussing the contribution of knowledge sharing among cities for the pursuit of collective goals such as global sustainability.

Sustainability is one of many urgent issues cities around the world are facing. Trying to find solutions means that cities must learn (by themselves or from other cities), and improve their information gathering and scanning systems (Marceau, 2008). Technology plays a central role in the pursuit of urban sustainability, considering that it is one of the most important features of modern cities (Gandy, 2005). Despite the potential competitive and environmental gains from the implementation of environmental technologies, diffusion has not happened at the expected pace (Montalvo and Kemp, 2008). This can be due to the rigidity of installed infrastructure and social systems, learning by doing and using, subsidies, and other lock-in mechanisms that hinder the diffusion of innovations (Geels et al., 2008).

Furthermore, the diffusion of environmental technologies can take different means with particular as well as common barriers. For example, diffusion could be through export, foreign direct investment, and technology transfer. Export is of strategic interest for firms and governments because it presents the opportunity to tackle environmental challenges as business opportunities while potentially 
contributing to environmental improvements (Kanda, 2014). However, firms exporting environmental technologies need to overcome certain export barriers. Export barriers are factors that discourage nonexporters from engaging in export or hinder the performance of existing exporters (Suarez-Ortega, 2003). Various categories of export barriers are identified in the scientific literature, e.g. barriers relating to firm size, export experience, ownership, and resource management in export (Kanda et al., 2012).

In particular, a common export barrier identified from the municipally owned companies relates to personnel resource management between home and export markets, since many of these companies often regard their municipal responsibility as a priority (Kairento and Nygårds, 2014). In addition, municipal ownership also presents some export barriers. For instance, under the Swedish Local Government Act, Swedish municipally owned companies are not allowed to build and operate large technical systems abroad. They are only allowed to export their knowledge and competence in the development and operation of such systems, which is considered a low-risk activity (Kanda, 2014). Other ownership-related barriers include the dependence on international aid organizations such as the Swedish International Development Cooperation Agency (SIDA) and owner municipality's financing to engage in export activities. Other export barriers relate to lack of knowledge and information about the export market characteristics such as consumer preferences, laws, regulations, and business opportunities. Differences between the home and target market in terms of business cultures, political systems, and levels of industrial development can also impede export (Kairento and Nygårds, 2014). In addition, there are also technology-specific barriers. In particular, large technical systems such as district heating supply, waste management, and renewable energy systems face significant barriers. These sectors are capital intensive, with a broad range of associated technical components, actors, and institutions (Markard and Truffer, 2006) that can be difficult to co-ordinate, particularly by a foreign company.

Bulkeley and Betsill (2005) claim that strategies addressing urban sustainability rely on proof-ofconcept projects, or "best-practices," something that Hodson and Marvin (2009) claim has triggered the emergence of what they call the "showcase city." In turn, networks aiming at creating standards through which cities can measure their environmental performance and share these best practices have emerged around the world (e.g. C40 and ICLEI). Other influential organizations have realized the need to promote the exchange of knowledge and best practices between and among cities, as is the case of the World Business Council for Sustainable Development (WBCSD, 2009:4): "Cities can learn from each other and history. [...] stakeholders can [...] benefit from the experiences-both good and badof other cities and apply this learning to their own situation."

An approach to city networks from economic theory provides a closer understanding of the positive externalities that justify participation in them, such as increased efficiency in decision-making processes, the achievement of critical masses for the implementation of specific projects, and access to know-how for the advancement of urban policies that is not available locally (Capello, 2000), which 
are in line with what has been discussed so far. International networking between cities has thus been seen as an effective way to solve environmental and social problems (Keiner and Kim, 2007). Each member benefits in a horizontal, rather than vertical way (Camagni and Capello, 2004; Mejía-Dugand, 2013), through relationships built on complementarity, rather than on the basis of distance or demand, and benefit from the interactive construction of collective goals, knowledge exchange, and unexpected innovations (Batten, 1995). Moreover, cities take the role of gateways that facilitate the further diffusion of ideas through their respective national and regional networks (Simmie, 2003). In this article, we want to explore the extent to which the five largest Swedish cities are participating in these networks, and their administrations' expected and perceived benefits from belonging to them.

\section{Methodology}

For this study, five Swedish cities were selected: Stockholm, Gothenburg, Malmö, Uppsala, and Linköping. These cities were chosen based on the size of their population, which was seen as a possible indicator for finding a larger number of network memberships, as previously observed by Keiner and Kim (2007). All cities, with the exception of Uppsala, are situated in top-ranked regions in relation to the total turnover from environmental technologies as reported by Statistics Sweden (see Table 1). Although the figures come both from the public and private sectors, the environmental technology sector's turnover was considered a plausible proxy of the city's involvement in that sector.

To start, a gross list of the international networks these cities belong to was made by visiting their official websites, which were considered to be the most accurate and easiest way to access this information, since it is centralized in one place. Being aware of possible out-of-date data in the cities' websites, we decided to contact those persons that appeared as responsible for the maintenance of the international networks and arranged interviews with them. Three interviews were performed by phone, and two were held face-to-face. The interviews lasted around one hour and were done using a semistructured approach, in which an interview guide was used mainly as a framework, but conversations evolved freely around the main topics of city networks and sustainability.

The conversations focused on the expected and perceived benefits from their membership in international city networks, the assessment and monitoring of activities and results, and the administrative processes required for joining and maintaining the networks. An important topic discussed was how central a role the municipal companies play in the city when it comes to addressing environmental problems, and how they have benefitted or expect to benefit from the cities' membership in international networks. The interviews were recorded and transcribed, in order to better analyze the data obtained from them. Finally, the interviewees were asked to provide an official list of the networks the city belonged to, in case the information listed on their website was not accurate or out of date. These data were later analyzed jointly by the research team, by identifying the key topics emerging from the interviews and performing cross-analyses among the cases and with the data found by visiting the different networks' websites.

Each identified network was analyzed by visiting their websites, in which we mainly checked the size of the network (number of members), their geographical reach (where members are located), their 
nature (goals or working areas) and the requirements for being a member. We searched for keywords that could be related to sustainability, such as "sustainability," "environment," "energy efficiency," "water management," "waste management," and "emissions reduction" for the assessment of their nature/orientation. When such keywords were found in the network's definition of goals, description of main activities and areas of focus, or mission statement, they were marked as sustainability-oriented networks. This data were collected in a database, which was later used to find patterns and analyze characteristics and trends. Table 2 provides more detailed information about the networks and the keywords found on their websites.

We are aware of the possibility of missing some networks. However, we trust that the information collected can be useful to reach our conclusions, especially since in most cases it was corroborated by city officials in charge of this particular topic. We are also aware of the existence of many other city networks, some of them initiated by other actors than the administration itself, e.g. universities. However, we limited our study to the ones reported by the administrations of the five studied cities.

\section{Results}

The research results are structured as follows. First, a quantitative analysis of the international city networks the studied cities belong to is presented. Subsequently, major themes emerging from the qualitative interviews with the cities are laid out.

\subsection{International city networks: Types, size, and geographical outreach}

For this study, it was assumed that the studied cities would all have memberships in at least one international network. It turned out to be so, with the number of memberships ranging from six to almost seventy. Also, it was expected that the largest cities would have more memberships than the smaller ones, and this was found to be the case, with the exception of Uppsala, which did not follow this pattern. Gothenburg, although smaller in population than the capital city Stockholm, was found to have a significant number of memberships in networks outside Europe. This fact is interesting because capital cities can access numerous networks outside the reach of other cities (for the mere fact of being the capital), so it can be a signal of the importance that the city of Gothenburg places on membership in international networks as a strategy to widen its global outreach. In particular, Gothenburg was found to belong to more networks with a clear focus on sustainability. Although it is difficult to find a causal relationship between the number of international networks and exports, Statistics Sweden reports similar levels of activity (in economic terms) of both cities and the regions they belong to when it comes to the exports of the environmental technology sector (see Table 1).

Each city has an office in charge of administering and maintaining the international networks. However, not all networks the cities belong to are administered by this office. Each city prioritizes the most important networks and appoints this office to take care of them. Other networks considered by this study are administered in a decentralized manner, i.e., other departments or municipal companies are in charge of their administration, according to their nature and goals. However, the central office is aware of all the networks the municipality and its branches belong to and keeps a record of them. Some of the cities meet annually or biannually in order to keep good track and inform the government 
in office about them. As described by the interviewees, one of the main challenges regarding the maintenance of these networks is the monitoring and assessment of the benefits they bring for the city. This is difficult to do because there are no clear and obvious connections to results in all cases. For example, job positions or energy savings are not always easy to relate to membership in a particular network. In any case, city officials try to analyze the advantages and disadvantages of belonging to certain networks, paying special attention to the resources needed to actually keep the membership active (e.g. human resources, travel, reports, fees) vs. the perceived benefits.

It was also found that each city, as expressed by the interviewees, has different expectations from their membership. It can be said that all cities are interested in attracting resources such as international companies, professional talent, and even tourism. However, some expressed more interest in finding funds for the development of local projects. What is most important, most cities recognized the potential of city networks to make their cities and their knowledge known abroad, to create milieus where they can contribute solutions to common problems, to provide important benchmarking opportunities, and to allow members to "learn from the best."

Only the interviewee from Uppsala mentioned an explicit strategy by the local government in office to increase the number of international networks the city belongs to. In many cases, there are networks to which the city belongs for historical or political reasons, but the administration does not see a direct benefit from doing so. Most cities, however, do not see the number of memberships as a determinant factor of their international strategy. Table 1 provides basic information about the studied cities and a summary of the data found about their memberships, while Table 2 provides detailed information about the networks for sustainability of which each studied city is a member (with the exception of Uppsala, which was not found to belong to any of these networks).

Table 1: General information about the city networks the studied cities belong to.

\begin{tabular}{|c|c|c|c|c|c|}
\cline { 2 - 5 } \multicolumn{1}{c|}{} & Stockholm & Gothenburg & Malmö & Uppsala & Linköping \\
\hline $\begin{array}{c}\text { Population (approx.) (SCB, 2014) } \\
\begin{array}{c}\text { Turnover in million SEK environmental } \\
\text { technology sector in 2013 (larger region) (SCB, } \\
\text { 2015) }\end{array}\end{array}$ & 900000 & 533000 & 313000 & 205000 & 150000 \\
\hline $\begin{array}{c}\text { Number of networks the city is a member of } \\
\text { nyyyyy}\end{array}$ & 69 & 46955 & 21140 & 4453 & 15703 \\
\hline
\end{tabular}




\begin{tabular}{|c|c|c|c|c|c|}
\hline Total number of members & $115000+$ & $45000+$ & $11000+$ & $500+$ & $1300+$ \\
\hline Networks outside Europe & 30 & 23 & 2 & 1 & 2 \\
\hline Geographical outreach & Global & Global & $\begin{array}{c}\text { Global, but mainly } \\
\text { within the EU }\end{array}$ & $\begin{array}{c}\text { Global, but mainly } \\
\text { within the EU }\end{array}$ & $\begin{array}{c}\text { Global, but mainly } \\
\text { within the EU }\end{array}$ \\
\hline $\begin{array}{c}\text { Memberships in sustainability } \\
\text { networks }\end{array}$ & 11 & 15 & 6 & 0 & 4 \\
\hline
\end{tabular}

Table 2: Information about the networks for sustainability each studied city belongs to (Uppsala was not found to belong to any network of this type).

\begin{tabular}{|c|c|c|c|}
\hline City & Name of the network & Web address & Keywords \\
\hline \multirow{11}{*}{ Stockholm } & ICLEI & http://www.iclei.org/ & $\begin{array}{l}\text { Sustainability, Resilience, } \\
\text { Biodiversity, Low-carbon, } \\
\text { Resource Efficiency, } \\
\text { Green Economy }\end{array}$ \\
\hline & ULI Urban Land Institute - Europe & http://europe.uli.org/ & $\begin{array}{l}\text { Urbanisation, } \\
\text { Conservation, } \\
\text { Regeneration, } \\
\text { Land Use, Sustainable } \\
\text { Development }\end{array}$ \\
\hline & $\begin{array}{l}\text { European Observatory Cities and } \\
\text { towns for All }\end{array}$ & http://w10.bcn.es/APPS/aaaoct/WeblangsServlet?pidioma=3 & Sustainable Development \\
\hline & $\mathrm{C} 40$ & http://www.c40.org/ & $\begin{array}{l}\text { Climate Change, GHG } \\
\text { Emissions }\end{array}$ \\
\hline & Eurocities & http://www.eurocities.eu/ & Climate \\
\hline & EUREAU & http://eureau.org/ & $\begin{array}{l}\text { Responsible Use, } \\
\text { Allocation of Scarce and } \\
\text { Vulnerable Resources, } \\
\text { Efficiency, Energy and } \\
\text { Nutrients Recovery } \\
\end{array}$ \\
\hline & $\begin{array}{l}\text { International Water Association } \\
\text { (IWA) }\end{array}$ & http://www.iwa-network.org/ & Water, Climate, Energy \\
\hline & $\begin{array}{l}\text { ESPO (European Sea Ports } \\
\text { Organisation) }\end{array}$ & http://www.espo.be/ & Environmental Protection \\
\hline & $\begin{array}{l}\text { IACP/AIVP (International } \\
\text { Association Cities and Ports) }\end{array}$ & http://www.aivp.org/en/ & $\begin{array}{l}\text { Climate Change, Energy } \\
\text { Transition }\end{array}$ \\
\hline & $\begin{array}{l}\text { PIANC (International Navigation } \\
\text { Association) }\end{array}$ & http://www.pianc.org/ & Environment \\
\hline & $\begin{array}{l}\text { International Society of } \\
\text { Arboriculture }\end{array}$ & http://www.isa-arbor.com/ & $\begin{array}{l}\text { Sustainable Communities, } \\
\text { Green Economy }\end{array}$ \\
\hline
\end{tabular}

Table 2 (Ctd.)

\begin{tabular}{|c|l|l|l|}
\hline City & \multicolumn{1}{|c|}{ Name of the network } & \multicolumn{1}{|c|}{ Web address } & \multicolumn{1}{c|}{ Keywords } \\
\hline \multirow{5}{*}{$\begin{array}{c}\text { Gothenbur } \\
g\end{array}$} & Eurhonet & http://www.eurhonet.eu/ & Energy Savings \\
\cline { 2 - 4 } & $\begin{array}{l}\text { International Federation of Housing and } \\
\text { Planning }\end{array}$ & http://www.ifhp.org/ & Green Growth, Climate Resilience \\
\cline { 2 - 4 } & $\begin{array}{l}\text { European Safety Stadium Management } \\
\text { Association }\end{array}$ & http://www.essma.eu/ & $\begin{array}{l}\text { Optimization, Environmental, Social and } \\
\text { Economic Benefits, Life Cycle }\end{array}$ \\
\cline { 2 - 4 }
\end{tabular}




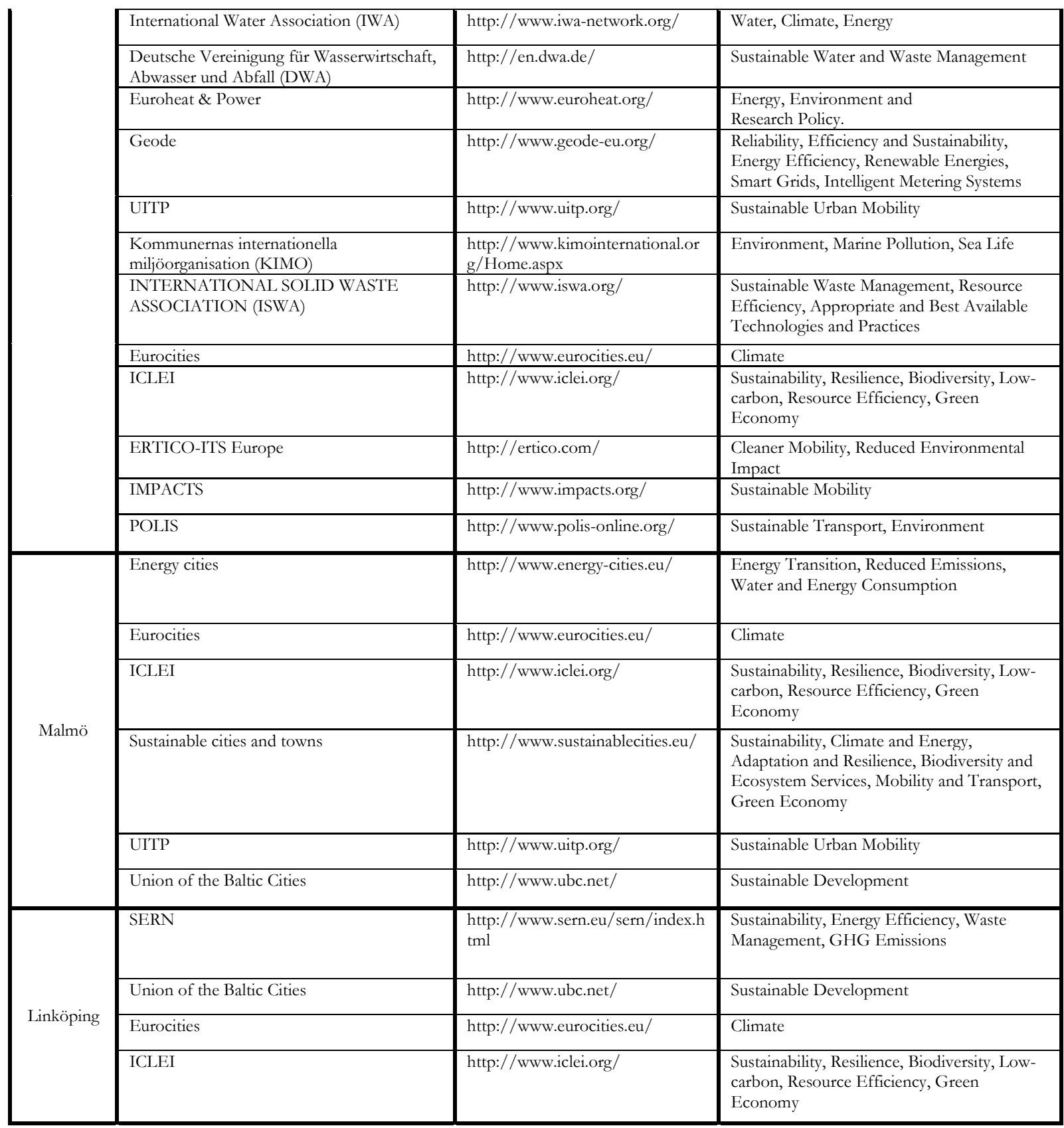

\subsection{Membership, subject focus, and other important aspects of international city networks}

In this section, results from the interviews with representatives from the selected cities on participation in networks are presented, classified under major themes emerging from the interview transcripts.

\section{i) Strategies to join networks}


With the exception of Uppsala, the studied cities do not have specific strategies regarding their membership in networks in the future. However, it was found that this depends greatly on the administration in office. Regarding environmental issues, the message in some cities was a long-term commitment to participation in certain networks, irrespective of the political majority since the main political parties prioritized such issues. This was confirmed by the interviewee from Stockholm:

"When it comes to environmental engagements, it is not foreseen that there will be major changes in the organizations that the city has decided to be involved in [...] because both political parties prioritize environmental issues."

In some cities, there are plans to revise their current membership in networks and increase them. There are no clear goals regarding the amount, but there are plans to develop assessment methods in order to decide which to keep, which to leave, and which to join. Strategic plans to increase the city's international visibility are of course more general in nature, but international networks are seen as a central contributor to this goal by all the studied cities.

\section{ii) Membership}

The two largest cities, i.e., Stockholm and Gothenburg, have a wider geographical span through their networks compared to the other cities. Although the majority of networks they belong to are focused on a national or European level, it is clear that their position as large cities or, in the case of Stockholm, as a capital, gives them visibility and allows them to belong to special types of networks outside the reach of smaller cities. There is a general positive opinion about membership in international city networks, although an interviewee from Linköping (i.e., the second smallest city in the study) mentioned that time requirements discourage their active participation in them:

"We are active in some national networks, not so active in the international networks because it takes a lot of time to be active members."

It was also found that not all memberships are kept alive because of the perceived benefits, but more for political or historical reasons. However, some of these networks are being disbanded and the studied cities are starting to focus more on joining or maintaining those networks that are focused on topics of their interest.

\section{iii) Subject focus}

Each city has its own interests and priorities when it comes to joining networks. The international offices normally report their interest in networks with broader coverage of urban topics, or "umbrella" networks, e.g. dealing with environmental sustainability, the economy, and social issues. However, municipal companies or specific branches of the city administration are also interested in more specific networks, e.g. library networks, parks and arenas networks or port networks. 
Most interviewees expressed the administration's interest for more broadly focused networks within which they can tackle several challenges together as is typically the focus of sustainability related networks. The interviewee from Uppsala, for example, put it like this:

“[...] if we can find broader networks like Eurocities, where many stakeholders from Uppsala can take part and can benefit from it, then we can have a broad decision to be members and more active, and the membership doesn't die when one person leaves the organization."

\section{iv) Participation in city networks for sustainability}

International city networks for sustainability are seen by most cities as relevant milieus where information and experiences can be shared. In particular, environmental technologies have found arenas where bidirectional flows are present, where cities can learn from the solutions other cities have implemented or also take advantage in order to promote their own solutions. Some cities have focused more on learning and bringing suitable technologies into their society, but the potential of networks as a means to promote their solutions in the future is openly recognized, as concluded by the interviewee from Linköping:

"It is not just to go out and think that our mission is to teach others, we have a lot to learn also and that will be the basis for dialogue."

\section{v) Expected vs. perceived benefits from city networks}

It was found that it can be difficult for cities to connect a specific outcome to a specific membership. However, it was clear that smaller networks (e.g. between three or four cities) have clearer aims and their direct benefits easier to identify, as many times they are created with a very clear and tangible goal, e.g. the improvement or construction of transport infrastructure. These networks are obviously of a different nature, since they are disbanded once the project is over, or continue in time just to administer the specific outcome of that project. Other cities are more concerned about the funding opportunities that some networks can provide them to finance some of their development projects. In an inventory made by the city of Gothenburg in 2013, councils and municipal companies were asked about their main reason for joining city networks. The main reasons given were "exchanging experiences" and "protecting their interests" (City of Gothenburg, 2013). Stockholm expressed expected benefits such as "publicity and attention for the city of Stockholm from the good projects and also to learn form the best to be able to develop our work." In Uppsala, participation in networks aims "to get knowledge from other cities and countries [...] that have solved problems that we are facing now so that we don't have to re-invent the wheel." In general, expected benefits might differ a lot since, as mentioned by the interviewee from Stockholm, "all network organizations are set up differently, and they have different resources and benefits for their members." In this line, most administrations agree that there is no clear methodology to evaluate benefits, more than perception and the outcome of regular follow-up meetings with those in charge of the networks and the local administration.

\section{vi) Benefits from international networks for municipal companies}


Benefits for municipal companies emanating directly from their owner city's participation in international networks were difficult to identify, according to the interviewees. This is due to the fact that municipalities and their municipal companies also engage in numerous activities outside these networks, and the quantification and direction of a given benefit is not always possible. In addition, activities within these networks are often focused on individual projects, not necessarily directed towards the specific sectors in which the municipal companies operate. However, interviewees mentioned perceived benefits from gaining access to multi-directional flows of information, receiving funding for specific projects, and attracting attention from foreign politicians and companies.

Municipal companies are seen as a necessary contribution to environmental, social, and economic issues by all the studied cities. The interviewees from the international offices were not normally in charge of administering those networks to which municipal companies belonged, which points to the fact that they have some level of independence to choose and run them.

Stockholm and Gothenburg provided the research team with an extensive and thoroughly classified report of all the networks the different agencies and companies of the city belonged to. From this list, it is seen that municipal companies in Gothenburg are more active when it comes to participation in international networks for sustainability, especially in the areas of energy, waste and wastewater management. In the case of Stockholm, the water management company is the most visible one from this perspective. The remaining memberships in both cities are administered either by the municipal government or by agencies in charge of managing e.g. arenas, public parks or transport, and as such were not considered companies in this study.

\section{vii) Administration of the networks}

It was highlighted during the interviews that cities that are members of these networks normally have the same right to vote or make decisions as the rest of the members, although it was made clear that being active and participating in meetings and conferences was necessary. This was an important issue to keep in mind when planning to join a network, as it requires the proper allocation of resources. Cities with stable political situations over the past years find it easier to maintain their memberships. This was confirmed by the interviewee from Gothenburg:

"There has been the same political majority in the city for the past 20 years [...] and thus there has been good continuity in the activities for international partnerships, cities and organizations that the city of Gothenburg is involved in."

\section{viii) Challenges/barriers to participation}

The most common challenge mentioned by the interviewees was the fact that politicians must be convinced about the benefits and the need to join a particular network. This has more to do with the actual effort and resources required to maintain it (e.g. full-time offices like the international office) than with membership fees, for example. In fact, many of the reported networks did not require the payment of a fee for membership. Smaller cities, however, find some obstacles when thinking of joining some of the networks, because of size and time requirements. Although some interviewees 
reported cultural differences as a challenge when joining international networks, it was clear that this could be solved with diplomacy and information, as emphasized by the interviewee from Uppsala:

"Challenges relate to understanding each other's language and culture and to be able to describe the challenges and opportunities in a way that has mutual understanding and benefits for both parties."

\section{Analysis/Conclusions}

In this study we aimed at answering two questions. First, we wanted to know to what extent the studied cities participate in city networks for sustainability. We found in our study that they all do, with the exception of Uppsala. We also found that there is a relatively large difference among them, i.e., Linköping belongs to four, while Gothenburg belongs to fifteen. Keiner and Kim (2007) found similar results in their study, i.e., the number of memberships varied widely. An interesting finding was that most cities want to take part in networks that cover a wide range of issues, as opposed to networks with a very narrow focus on an environmental sustainability issue, e.g. air pollution. The interviewees mentioned that networks with a wide focus provide more flexibility and the opportunity to include more members and benefit more stakeholders. It was found that Gothenburg is the city that belongs to more networks for sustainability. Stockholm, on the other hand, has access to more members through all of its networks. This might not only be because it belongs to more networks than the rest, but also because of its position as the capital and the advantages that this position brings.

We also found that all the studied cities have access to members around the globe through at least one of their networks (as in the case of Uppsala). However, Stockholm and Gothenburg have the widest reach. This is not only because they are members of more networks outside Europe than the others, but also because of the actual networks they are members of. There are some networks that, because of their nature, offer the opportunity to access a larger number of members. For example, some networks focus only on cities as members, while other accept different companies from the same city or have different membership categories (e.g. city governments and individual experts), which increases the number of possible contacts each member has. Access to a wider variety of members from all over the globe might be beneficial to cities, given the demands that have emerged with the globalization process and the pool of knowledge that such milieus can provide. Considering the horizontal linkages between members in these networks and the positive externalities of belonging to them, cities with a wider outreach may find more successful cases of e.g. urban policies and technologies implementation and, in line with the aim of this article, more potential recipients of their ideas and environmental technologies.

The second question relates to how municipal companies benefit from their city's participation in networks when it comes to the diffusion of their environmental technologies. As mentioned in the results section, belonging to international networks of cities sharing knowledge and experiences, providing creative solutions and applications, and supporting each other in a continuous matter, represents benefits and might facilitate the achievement of environmental, development, and commercial goals. We recognize that there is a possibility of finding biased positive expectations and 
views of the actual benefits of belonging to city networks from the city officials in charge of administering them. This does not necessarily affect the results discussed in this article. Capello (2000) discusses that the achievement of the most strategic network advantages depends on the active participation of those involved, which in turn requires from them a positive mental attitude toward these networks and the organizational changes they entail.

In reconciling the barriers to the diffusion of environmental technologies to the dynamics of participation in city networks, we acknowledge that not all barriers can be tackled by participation in such networks. Nonetheless, participation in city networks offers two benefits in particular: building legitimacy and having access to information. These conditions are essential for the diffusion of environmental technologies (Kanda, 2014). Legitimacy refers to social acceptance, the compliance with relevant institutions and regulations including the ability to meet formal and informal expectations (Bergek et al., 2008). Participation in city networks provides the opportunity for municipalities to share information on their environmental challenges and how they have been solved, expose their local company competence, and show their expertise to potential customers.

Members of such networks (especially with a sustainability focus) share common goals and facilitate the strengthening of legitimacy and the development of their competencies related to the achievement of these goals. Such legitimacy is what municipal companies can gain from their owner municipalities, particularly for the diffusion of environmental technologies. In addition, city networks provide a unique platform for two-way information sharing between and among the members. Gathering and delivering market information such as consumer preferences, laws, regulations, business opportunities, policy and regulations can help municipal companies to facilitate the diffusion process, which results in both environmental and economic benefits.

As can be concluded from the above discussions, city networks have the potential of contributing to the diffusion of environmental technologies, and thus to global sustainability. The realization of such benefits depends on several factors, such as the subject focus of the network, the members' use of the networks, and contextual characteristics of the member cities. In the case of Swedish municipalities, their legal restriction to export only knowledge and competence of large technical systems has a limiting effect on how much such companies can benefit from their participation in city networks, at least from a commercial perspective. However, they can still contribute with best practices for other cities' advancement in sustainability terms, and benefit from the possibility of attracting environmental technologies and foreign companies into their own cities.

\section{Generalization of the results}

Although this study focused on municipal companies, it is clear that private companies can also benefit from the membership in city networks of the city in which they operate. Some Swedish cities have trusted private utility companies (e.g., Norrköping) to administer their utilities infrastructure, so these companies benefit from the knowledge gathered while administering the cities' utilities, from official visits to the city performed by foreign delegations, from research studies that can result from joint projects with academia or other cities, and from the access to information and contacts that the city 
can gain through its memberships in different networks. Since private companies do not have the same restrictions as municipal companies, they have more economic incentives and freedom to explore opportunities in cities outside Sweden and thus, the potential to contribute more to achieving sustainability goals where they operate.

Each country has its own particular characteristics dictated by, among other things, their regulations, their climate, their political milieu, and the resources they have. These conditions can also have an impact on the negotiating power its cities have in international markets and the political influence they can exert on decisions that can affect sustainability goals on a regional or even global level. However, it was found in this study that members of international networks normally have full rights and that there is no practical possibility to influence decisions based on the mentioned advantages, since these networks' raison d'etre is to benefit all their members equally, and their mission is to represent all their members' best interests, depending on each network's focus. With this in mind, it is reasonable to assume that the results from this study are useful to cities outside Sweden and outside Northern Europe. The benefits of belonging to international city networks in general that were mentioned above do not depend on geographical or political conditions, but are inherent of networks and the way they function. This does not change when talking about networks for sustainability, since we discussed that cities benefit from the exchange of knowledge and best practices abroad, and the pressure that groups of cities can exert on other arenas in which crucial decisions that affect global sustainability goals are discussed.

\section{Acknowledgements}

The authors want to thank the Swedish Governmental Agency for Innovation Systems (VINNOVA), the Swedish Energy Agency, and Tekniska Verken AB for their financial support. A big thank you goes to Malin Parmander, Christian Dahlmann, Fredrik Nielsen, Helena Kock Åström and Björn Bertilsson, who kindly shared their time and knowledge with the research team. Also, thanks to Anitha Muralidhara, who was of great help for the collection of information about the cities and their networks.

\section{References}

Baptista, R., 2001. Geographical clusters and innovation diffusion. Technological Forecasting and Social Change 66, 31-46.

Batten, D.F., 1995. Network cities: creative urban agglomerations for the 21 st century. Urban Studies 32(2), 313-327.

Bergek, A., Jacobsson, S., Carlsson, B., Lindmark, S., Rickne, A., 2008. Analyzing the functional dynamics of technological innovation systems: A scheme for analysis. Research Policy 37, 407429.

Bulkeley, H., Betsill, M., 2005. Rethinking sustainable cities: Multilevel governance and the 'urban' politics of climate change. Environmental Politics 14(1), 42-63. 
Camagni, R., Capello, R., 2004. The City Network paradigm: Theory and empirical evidence. In: Capello, R., Nijkamp, P. (Eds.), Urban Dynamics and Growth: Advances in Urban Economics. Emerald, Bingley, pp. 495-529.

Capello, R., 2000. The City Network paradigm: Measuring urban network externalities. Urban Studies 37(11), 1925-1945.

City of Gothenburg, Stadsledningskontoret, 2013. Inventering av Göteborgs Stads medlemskap i internationella organisationer år 2013 [Inventory of Gothenburg City's membership in international organizations year 2013]. Dnr: 1592/13.

Cooke, P., Davies, C., Wilson, R., 2002. Innovation advantages of cities: From knowledge to equity in five basic steps. European Planning Studies 10(2), 233-250.

Furlong, K., 2014 (In Press). Water and the entrepreneurial city: The territorial expansion of public utility companies from Colombia and the Netherlands. Geoforum, http://dx.doi.org/10.1016/j.geoforum.2014.09.008.

Gandy, M., 2005. Cyborg urbanization: complexity and monstrosity in the contemporary city. International Journal of Urban and Regional Research 29(1), 26-49.

Geels, F.W., Hekkert, M.P., Jacobsson, S., 2008. The dynamics of sustainable innovation journeys. Technology Analysis \& Strategic Management 20(5), 521-536.

Guy, S., Marvin, S., 1999. Understanding sustainable cities: Competing urban futures. European Urban and Regional Studies 6(3), 268-275.

Hansson, S.O., 2010. Technology and the notion of sustainability. Technology in Society 32, 274279.

Hillman, K., Nilsson, M., Rickne, A., Magnusson, T., 2011. Fostering sustainable technologies: a framework for analyzing the governance of innovation systems. Science and Public Policy 38(5), 403-415.

Hodson, M., Marvin, S., 2009. Cities mediating technological transitions: understanding visions, intermediation and consequences. Technology Analysis \& Strategic Management 21(4), 515-534.

Hodson, M., Marvin, S., 2010. Can cities shape socio-technical transitions and how would we know if they were? Research Policy 39, 477-485.

Hult, A., 2013. Swedish production of sustainable urban imaginaries in China. Journal of Urban Technology 20(1), 77-94.

Kairento, K., Nygårds, M., 2014. Export of municipal environmental technology knowledge. An analysis of previous activities and incentives. Master's Thesis. Environmental Technology and Management, Department of Management and Engineering, Linköping University. LIU-IEITEK-A--14/01823-SE.

Kanda, W., 2014. Promotion of environmental technology export. Governmental initiatives and business concepts. Linköping Studies in Science and Technology. Licentiate thesis No. 1673.

Kanda, W., Mejía-Dugand, S., Hjelm, O., 2015. Governmental export promotion initiatives: awareness, participation, and perceived effectiveness among Swedish environmental technology firms. Journal of Cleaner Production. http://dx.doi.org/10.1016/j.jclepro.2013.11.013.

Kanda, W., Hjelm, O., Mejía-Dugand, S., 2012. Environmental Technology Export Promotion: A study of governmental initiatives in selected countries. Environmental Technology and 
Management, Linköping University. Report LIU-IEI-R; 12:005.

http://urn.kb.se/resolve?urn=urn:nbn:se:liu:diva-80261 [Accessed September 12, 2014].

Keiner, M., Kim, A., 2007. Transnational city networks for sustainability. European Planning Studies 15(10), 1369-1395.

Marceau, J., 2008. Innovation in the city and innovative cities. Innovation: Management, Policy \& Practice 10, 136-145.

Markard, J., \& Truffer, B., 2006. Innovation processes in large technical systems: Market liberalization as a driver for radical change? Research Policy 35(5), 609-625.

Mejía-Dugand, S., 2013. Diffusion of environmental technology in a megacity - A case study of Mexico City. Linköping Studies in Science and Technology. Licentiate thesis No. 1574. LIUTEK-LIC-2013:8.

Mejía-Dugand, S., Hjelm, O., Baas, L., Ríos, R.A., 2013. Lessons from the spread of Bus Rapid Transit in Latin America. Journal of Cleaner Production 50, 82-90.

Montalvo, C., Kemp, R., 2008. Cleaner technology diffusion: case studies, modeling and policy. Journal of Cleaner Production 16S1, S1-S6.

Nicholls, W.J., 2008. The urban question revisited: The importance of cities for social movements. International Journal of Urban and Regional Research 32(4), 841-859.

Pedersen, P.O., 1970. Innovation diffusion within and between national urban systems. Geographical Analysis 2(3), 203-254.

Simmie, J., 2003. Innovation and urban regions as national and international nodes for the transfer and sharing of knowledge. Regional Studies 37(6\&7), 607-620.

Statistics Sweden (SCB), 2014. Folkmängd i riket, län och kommuner efter kön och ålder 31 december 2013 [National, county and municipal population classified by gender and age 31 December 2013]. http://www.scb.se/sv_/Hitta-statistik/Statistik-efteramne/Befolkning/Befolkningenssammansattning/Befolkningsstatistik/25788/25795/Helarsstatistik---Kommun-lan-ochriket/159277/ [Accessed September 12, 2014].

Statistics Sweden (SCB), 2015. Environmental sector by county, 2013. http://www.scb.se/en_/Finding-statistics/Statistics-by-subjectarea/Environment/Environmental-accounts-and-sustainable-development/System-ofEnvironmental-and-Economic-Accounts/Aktuell-Pong/38171/Environmental-sector/317383/ [Accessed August 27, 2015].

Suarez-Ortega, S., 2003. Export Barriers: Insights from small and medium-sized firms. International Small Business Journal 21(4), 403-419.

The World Bank, 2010. Cities and climate change: An urgent agenda. Washington, D.C.: The World Bank.

UNHABITAT, 2012. The future we want. www.unhabitat.org/downloads/docs/11279_1_594479.pdf [Accessed October 21, 2013].

World Business Council for Sustainable Development (WBCSD), 2009. Mobility for Development. www.wbcsd.org/Pages/Adm/Download.aspx?ID=164\&ObjectTypeId=7 [Accessed August 27, 2015]. 


\section{ANNEX - Cities' official information on international networks on the internet}

- Gothenburg: http://goteborg.se/wps/portal/invanare/kommun-o-politik/internationelltsamarbete/om-internationellaavdelningen/!ut/p/b1/jYvBCoJAFEW_pR_w3XGc8c3yJaWFCQpCziYsQgRHN1G_n31A1Nk dOIc8dXFsoVKjQWfyc_8ch_4xLnM_fdzbS6tQ81YJcmZAMpx2makUN3oNujXIcimStAS4zA 0OUrSNq7WG6P9-fEHw6z-

SH68het1ChChFbJlZWXYu0c5QVSzhTsFPex5k8wZsXsFp/dl4/d5/L2dBISEvZ0FBIS9nQSE h/ [Accessed September 14, 2014].

- Linköping: http://www.linkoping.se/Om-kommunen/Utveckling-ochsamverkan/Internationellt-samarbete/Internationella-natverk/ [Accessed September 14, 2014].

- Malmö: http://www.malmo.se/Kommun--politik/Sa-arbetar-vi-med.../Omvarld/Internationelltarbete/Internationella-natverk.html [Accessed September 14, 2014].

- Stockholm: http://www.stockholm.se/OmStockholm/EU--Internationellt-/Internationellaorganisationer-och-natverk/ [Accessed September 14, 2014].

- Uppsala: http://www.uppsala.se/sv/Kommunpolitik/Internationellt-arbete/Natverk/ [Accessed September 14, 2014]. 